\title{
The Namesake: A Study of Cultural Dissonance
}

\author{
Manish Kumar Ishan \\ Research Scholar \\ Babasaheb Bhimrao A Bihar University \\ Muzaffarpur, Bihar, India \\ ishanmanish@gmail.com
}

\begin{abstract}
The proposed research article is an attempt to make an analysis of the causes of cultural dissonance in the Jhumpa Lahiri's novel, The Namesake. Cultural conflict has been a constant motif of Indian diasporic writers, presented by Lahiri in the form of Immigrant's experience, in evocative manner. It is observed that for immigrants, the challenges of exile, feeling of displacement and longing for homeland and desire for acquiring identity in a new world is more explicit and distressing than for their offspring. The Namesake is basically a narrative of Indian Bengali family who comes to America for better future prospects; it discusses dilemma of cultural clash and identity in an alien land.
\end{abstract}

Keywords: Immigrants, Identity, Culture.

Cultural dissonance has been one of the recurrent themes of Lahiri's oeuvre. She primarily deals with the issues of exiles, displacement, cultural conflict, identity crisis and the the feeling of nostalgia and alienation of Indian immigrants to America. Her fictional voices find expression through the cultural dilemmas and displacement of Indian diaspora. In the novel, 
The Namesake she underlines the cultural dilemmas and displacement of a Bengali family and their difficulty in reconciling the native cultural practices with an alien culture. Lahiri portrays the cultural dislocation of their characters in terms of acculturation of Indian immigrants to American ways of life. New York Times writes about this novel: This is a novel as affecting in its Chekhovian exploration of fathers and sons, parents and children as it is resonant in its exploration of what is acquired and lost by immigrants and their children in pursuit of the American dream. The writer examines the cultural dilemmas of her characters in two ways firstly, the first generation Indian immigrants find it difficult to assimilate the cultural practices of the host culture. Secondly, the second generation immigrants do not want to accept the life style of their parents and they want themselves to be recognized as a native person of the host society. The first generation immigrants reluctantly adopt the customs of foreign country. In the novel, we find that earlier Ashok was hesitant in accepting the celebration of Christmas and Thanksgiving. After the demise of Gogol's father, Lahiri quotes, "it was for him (Gogol), for Sonia (Ashoke's daughter) and that his parents had gone the trouble of learning these customers. (The Namesake, 286)

As Lahiri's parents belonged to the first generation of Indian diaspora and she herself belonged to the second generation of Indian diaspora; therefore, she was well aware of the mindset different generations of Indian diaspora, presents their experiences, points out its significance in the context of cultural dislocation. She quotes:

In fact, it is still very hard to think of myself as an American. For immigrants the challenges of exile, the loneliness, the constant sense of alienation, the knowledge of longing for a lost world, are more explicit and distressing than for their children. On the other hand, the problems for the children of immigrants, those with strong ties to their country of origin, are that 
they feel neither one thing nor the other. The feeling that there was no single place to which I fully belonged bothered me growing up.(An interview with Jhumpa Lahiri, Book Browse)

This seems to be the experience of not only Lahiri's culturally displaced life, but also of Gogol (the protagonist of The Namesake). He, representative of second generation of Indian diaspora, suffers from fractured identity because of his typical name. This is what Lahiri highlights in The Namesake, Nikhil Gogol born in the US and as an US citizen by birth, finds himself unable to adjust in the company of his parents' acquaintances. He feels culturally alienated because of the unusual appearance of his own name and at great extent because of the customs and cultural practices of their parents, which is imposed upon him by his parents. Gogol is seen to be least bothered about imbibing and retaining the essence of their Bengali background. He attends the classes of Bengal language and culture lessons, "without interest, wishing they could be at ballet or softball practices instead" like typically American children, hated attending them too. (66)

On the contrary, Ashoke and Ashima always try to create equilibrium between Indian and American culture. They work and behave like all normal American people except for receiving issues of India abroad and Sangbad Bichitra, Gogol appears as an authentic American than they are, hardly visits to Calcutta or the annual pujo held at one of the local community halls where "they were required to throw marigold petals at cardboard effigy of goddess and eat bland vegetarian food." (64) To him Christmas appears to be more interesting than Durga Pujo of Indian Bengali community. Thus Ashima tries to remain connected with her home through the threads of cultural practices. As Iian Chamber quotes it:

We can never go Home, return to the primal scene, to the forgotten moment of our beginnings and "authenticity," for there is always something else between. We cannot return to a bygone 
unity, for we can only know the past, memory, the unconscious through its effects, that is when it is brought into language and from there embark on an (interminable) analysis. In front of the "forest of signs" (Baudelaire) we find ourselves always at the crossroads, holding our stories and memories ("secularized reliques," as Benjamin, the collector, describes them) while scanning the constellation full of tension that lies before us, seeking the language, the style, that will dominate movement and give it form. Perhaps it is now a question of seeking to be at home here, in the only time and context we have. (Chambers Iain, Border Dialogues)

The first generation life in an alien land is all about adaptation and learning, acculturing, and also discovering new things about themselves. Whereas, the life of second generation immigrant revolves around establishing their identity with two conflicting realities and cultures. There is sharp contrast between the socio-cultural surroundings of their host country and the native country.

Ashima is the first generation immigrants, her emotional attachment and feeling of nostalgia, haunts her all the time after coming to America. She comes to America with her husband Ashoke, with a view to lead a happy and prosperous life for the rest of her life. But her physical and emotional detachment from her loved ones makes her life burdensome. She yearns to go back to her native land. At the outset of the novel readers can easily find that Ashima remains lost in the memory of her home. Most of the time, she remains recalling the activities going there by calculating "the Indian time on her hands" which is ten and a half hours ahead in Kolkata. In order to get rid of her loneliness and feeling of homesickness she keeps reading Bengali short stories, poems and articles, from the Bengali magazines she has brought from India. She is so terrified to think about her "motherhood in a foreign land... so far from home, unmonitored and unobserved by those she loved" (205) 
After the birth of Gogol, Ashima wishes to return her homeland in order to bring her child in the company of the caring and loving ones. However, she remains in America for her husband's sake. She is the real embodiment of Indian mother, who sacrifices her pleasures for her husband. In this way, Lahiri presents the culture and tradition of Indian family. One of the greatest concern and challenge before Ashima is to raise her children according to the Bengali customs and culture, which she hardly finds feasible in her case. She does not feel at home with her American counterparts, she rather feels lonely and culturally dislocated. She begins to realize:

“Being a foreigner ...is a short of life long pregnancy - a perpetual wait, a constant burden, a continuous feeling out of sorts is an ongoing responsibility. A parenthesis in what had once been ordinary life, only to discover that previous life has vanished, replaced by something more complicated and demanding. Like pregnancy, being a foreigner, Ashima believes, is something that elicits the same curiosity from strangers, the same combination of pity and respect."(163)

Ashima's constant effort to preserve her home culture in the new ambience makes her feel more culturally displaced, she tries to sow the seed of native culture in her children's mind. She exposes them to their own family lineage, food tastes, habits and mannerism. She teaches Gogol:

To memorize a four line children poem by Tagore, and the names of the deities adorning the ten headed Durga during puoj: Sarswati with her swan and Kartik with his peacock to her left, Lakshmi with her owl and Ganesh with his mouse to his right. Every afternoon Ashima sleeps, but before nodding off she switches the television to channel 2. And tells Gogol to watch sesame street and The Electric Company, in order to keep up with the English he uses at nursery school. (54) 
In this way, Lahiri elucidates immigrants' cultural dilemma and difficulty in a foreign soil. Generally, immigrants' cultural practices might appear responsible for their cultural dislocation. In the novel, Lahiri shows how the cultural practice of having two names - pet names at home and good names (Bhalo name) for formal purpose proves a curse for Gogol. He finds himself culturally dislocated because he neither belongs to India nor does he get social affiliation in the foreign country.

When Gogol first met Maxine parents he is shocked to see the openness with which they lead their life. At the same time what strikes him is their life style. When Maxine served food he finds it frugal as compared to the food served by his mother to their guests. On another occasion when Maxine's guests discuss movies, art exhibits, restaurant, etc. Gogol feels it hardly interest his parents:

Gogol is unaccustomed to this sort of talk at mealtimes, to the indulgent ritual of lingering meal, and the pleasant aftermath of bottles and crumbs and empty glasses that clutter the table. (134)

Gogol visits to Maxine's house provides him an opportunity to learn the American ways of life. He also finds that unlike his parents Maxine parents take care of her likes and dislikes and leaves her to spend her life according to her choice. Thus, Lahiri through the eyes of Gogol, judges the cultural difference between Americans and Indians. Gogol is highly influenced by the language and cultures of American people, its fascination creates in him scant respect for Indian culture. He feels comfortable with Maxine and her American life style. Ngugi Wo Thiong quotes:

“...language carries culture, and culture carries, particularly through culture and literature, the entire body of values by which we come to perceive ourselves and our place in the world. How 
people perceive themselves affects how they look at their culture, production of wealth, at their entire relationship to nature and other human beings. (Beginning Post-Colonialism, 18).

In the novel, Lahiri analyses the psychic condition of the first generation immigrants and second generation immigrants to America. In an attempt to perpetuate their traditions and rituals in a foreign land, both Ashima and Ashoke maintain their ties with Indian culture. They often take part in gatherings with their Bengali friends and occasionally visit to India. In order to keep their Bengali identity intact, and making an important decision, they pay heed to the advice of their community: "each step, each acquisition, no matter, how small, involves deliberation, consultation with Bengali friends." (64)

They not only practice their own culture but also assimilate the American culture and lifestyle. Thus, they assume a new 'hybrid identities'. The identity of second generation is at stake and a conflicted one. They are supposed to follow Indian culture and value system at their homes, while their public life is guided by American code of conduct. Thus, they are caught in a state of limbo and assume a fractured identity. For them, home of their parents, appear as a mystic place of desire, often situated in the Cultural landscape of diasporic imagination. Salman Rushdie aptly quotes:

"our physical alienation from India almost in veritably means that we will not be capable of reclaiming precisely those things they were lost; that we will, in short, create fictions, not actual cities or villages, but invisible one, imaginary homelands, Indians of the mind. (Beginning Post Colonialism, 211)

Being a second generation diasporic writer, Lahiri herself went through similar experience in her life. This is what she precisely articulates in The Namesake with empathetic tone. Gogol acts as a mouthpiece of Lahiri, who observes a great difference between identity his 
mother tries to preserve, after coming to America, and the identity she wants to create for him. His mother wishes to keep her Bengali traditional values alive which practically seem to be unacceptable for Gogol. This state of 'being' and 'becoming' is the root cause of cultural dissonance among the characters of The Namesake.

The characters in Lahiri's fiction are caught drifting between the two worlds and two cultures; one is the host country where they reside and another is their parents' homeland. They have dual identity. They are neither accepted by host society nor do they have connection with their parents' homeland. Homi Bhabha opines that diasporic community is subjected to cultural indeterminacy and hybridity which rejects fixed identity. Bhabha quotes:

A doubling dissembling image of being in at least two places at once which makes it impossible...to accept the invitation to identity: 'you are a doctor, writer, a student, you're different. It is precisely in that ambivalent use of 'different'- to be different from those that are different makes you to see- that the unconscious speaks of the form those that are different of otherness, the tethered shadow of deferral and displacement...(Post-Colonial Criticism,365)

Conclusion:

It can be easily observed that in The Namesake adolescent and emerging adults have interactions with people from diverse culture, either first-hand experience (in case of Gogol in the context of America) or indirectly through various media: here, Gogol comes to know about India through his parents. In this way, developing a cultural identity becomes more complex, no longer is a question of becoming an adult member of one culture but instead of it is related to negotiating multiple cultures. The writer has highlighted, when she discusses first generation immigrant, how the new complexity of identity development goes together with increased 
diversity of possible identities. A person's identity is determined in many different ways depending upon individual choices and the cultural influence of the place where he or she resides in. Lahiri's perception of identity formation centers on how members of a certain cultural group negotiate their identification with their own group and also in the context of living among other cultural groups. 


\section{References}

Lahiri, Jhumpa. The Namesake. Uttar Pradesh: Harper Collins Publisher, 2008, Print

Kakutani, Michiko. BOOKS OF THE TIMES; From Calcutta to Suburbia: A Family's

Perplexing Journey. The New York Times, Inc Sept. 2, 2003, www.nytimes.com/2003/09/02/books/books-of-the-times-from

An interview with Jhumpa Lahiri, Book Browse.

https://www.bookbrowse.com/author_interviews/full/index.cfm/author_number/929/jhu mpa-lahiri

McLeod, John. Beginning Post-Colonialism, New York: Manchester University Press, 2000.

Iain Chambers, Border Dialogues: Journeys in Post-Modernity (London: Routledge, 1990), 104.

Das Kumar, Bijay. Post-Colonia Criticism, Delhi. Nice Printing press, 2005 